
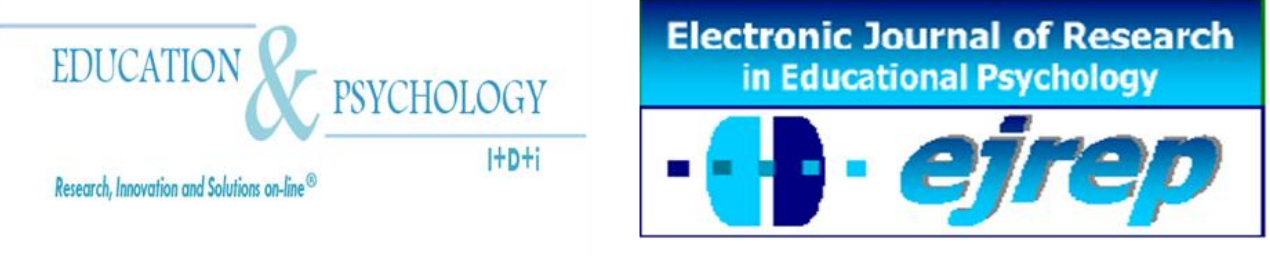

Editorial EOS

\title{
Family Socioeconomic Status and Student Adaptation to School Life: Looking Beyond Grades
}

\author{
Renato G. Carvalho \& Rosa F. Novo
}

Centro de Investigação em Psicologia, Universidade de Lisboa

\section{Portugal}

Correspondence: Centro de Investigação em Psicologia, Faculdade de Psicologia, Alameda da Universidade, 1649-013 Lisboa, Portugal. E-mail: renatoggc@gmail.com

(C) Education \& Psychology I+D+i and Editorial EOS (Spain) 


\begin{abstract}
Introduction. In this quantitative, cross-sectional study we analyse the relationship between family socioeconomic status (SES) and students' adaptation to school life, as expressed through several indicators of achievement, integration (adaptation to transitions, behaviour problems, risk behaviours, interpersonal difficulties, participation in extracurricular activities) and overall satisfaction. It was our goal to understand if students' SES is a contributing factor for the individual differences in several school life dimensions, beyond grades, which have been usually the most prominent marker of school success.

Method. Participants were 351 ninth to twelfth grade Portuguese students (ages 14-18 years) and the instrument that collected data concerning several school life dimensions was the School Path Questionnaire, which was designed for this study. Data was thereafter analysed through multivariate statistical analysis.

Results show a positive association between students' SES and school adaptation, with significant differences between the groups on most school life dimensions, namely school grades, number of retentions, school achievement, participation in extracurricular activities, interpersonal difficulties, adaptation to school transitions, and overall satisfaction about school life. The most significant differences were observed in performance related variables. It was the highest SES group that differentiated most from the remaining groups.

Discussion. The pattern of results is discussed concerning the role of contextual variables such as family and community on school success and integration, and the necessity of educational interventions in order to compensate students' unfavourable starting socioeconomic conditions at school.
\end{abstract}

Keywords: Socioeconomic Status; School Life; School Success; Adolescents

Received: 07/16/12 Initial acceptance: 07/19/12 Final acceptance: 10/30/12 


\section{Estado socioeconómico familiar del alumno, y su adaptación a la vida escolar: más allá de las calificaciones}

\section{Resumen}

Introduction. En este estudio cuantitativo y transversal se analiza la relación entre el estatus socioeconómico familiar (ESE) y la adaptación de los estudiantes a la vida escolar, expresa a través de varios indicadores de rendimiento escolar, de integración en la vida escolar (la adaptación a las transiciones, los problemas de comportamiento, las conductas de riesgo, las dificultades interpersonales, la participación en actividades extracurriculares) y de satisfacción global. Nuestro objetivo principal ha sido comprehender si el ESE de los estudiantes es un factor contributivo para las diferencias individuales en varias dimensiones de la vida escolar, más allá de las notas escolares, que han sido normalmente consideradas el principal indicador de suceso escolar.

Método. Los participantes fueron 351 estudiantes portugueses de noveno a doceavo grado (edades 14-18 años) que respondieron al Cuestionario sobre la Vida Escolar, construido para esto estudio. Los datos fueran analizados mediante el análisis estadístico multivariado.

Resultados. Ha sido identificada una asociación positiva entre el éxito de los estudiantes y su ESE, con diferencias significativas entre los grupos en la mayoría de las dimensiones, a saber, las notas escolares, el número de retenciones, rendimiento escolar, la participación en actividades extracurriculares, dificultades interpersonales, adaptación a las transiciones de la escuela, y la satisfacción general con la trayectoria escolar. Las diferencias más significativas se observaron en las variables relacionadas con el rendimiento escolar. Fue el grupo de mayor SES que más se ha diferenciado de los demás grupos.

Discusión. Los resultados son discudios considerando el papel de las variables contextuales, como la familia y la comunidad, en la integración escolar de los estudiantes, y la necesidad de intervenciones educativas para compensar estos efectos socioeconómicos desfavorables.

Palabras-clave: Estatus Socioeconómico; Vida Escolar; Suceso Escolar; Adolescentes 


\section{Introduction}

The identification of significant variables to students' school success has always been a prominent area of research in educational settings. There have been pointed out several variables that contribute to success, including students' individual characteristics (e.g., intelligence, aptitudes, personality, attribution styles or future time perspective), the school and the education system organisational dimensions, and variables related to social and cultural contexts, such as socioeconomic status (SES), which we focus in this study. Nevertheless, research involving SES effects on school context has been focusing mostly grades or performance as the main indicator of success. This is why we consider relevant to assess whether SES has a broader impact in school context, that is, if SES can be related not only with school grades but as well with other indicators of adaptation to school life. The present paper intends then to deliver some response to this goal, by studying differences between students with different SES on several school life dimensions, representative not only of school performance, as expressed in grades, but as well of school life integration (interpersonal relationships, frequency of risk behaviours and behaviour problems, adaption to transitions, and participation in extracurricular activities), and overall satisfaction about it. Because of this wider focus in different dimensions and concerning a specific population reality, we therefore think this can be a contribution to the study of adaptation to school life and particularly to the factors that are related to it.

Independently from the several criteria to identify SES, such as family income, parental qualifications or their professions, research has demonstrated that it is related to a large array of cognitive, socio-emotional and health-related aspects in children and adolescents, with effects manifesting even before birth and that may remain in adult life (Bradley \& Corwyn, 2002). In the specific school domain, investigation has consistently emphasized the positive relationship between SES and students' academic performance (Almeida, Guisande, Soares, \& Saavedra, 2006; Caro, McDonald, \& Willms, 2009; Saavedra, 2001; Strenze, 2007). For instance, Sirin (2005), in a meta-analysis, reports several differences in school performance among students, depending on their SES.

The explanation for the association between SES and school results involves the better physical, emotional and intellectual development opportunities that higher SES students' potentially have (Feitosa, Matos, Del Prette, \& Del Prette, 2005). In fact, SES involves the 
access to material resources, habitation quality, health care and other services, social networks, stimulating experiences and positive parental styles (Bradley \& Corwyn, 2002; Feitosa et al., 2005), all of which can create more favourable conditions for success and adaptation at school. These social, cultural and economic resources can all be included in what one can name as the family cultural capital (Marks, McMillan, Jones, \& Ainley, 2000). This circumstance is even more prominent if we consider the higher proximity and identification with the school official pedagogical discourse that high SES families potentially have (Pires \& Morais, 2000).

This means therefore that underprivileged social groups can be at higher risk of learning difficulties, behaviour problems presentation and even school dropout (Almeida et. al., 2005; Feitosa et al., 2005). In effect, some studies indicate that children from low SES families start school in average with significant poorer academic competences and tend to remain in that condition, even those who benefit from precocious interventions (Arnold \& Doctoroff, 2003; Stipek, 2001). The weak academic competence at early school may thereafter incite or at least exacerbate behavioural problems that affect future learning, being in that way created a vicious cycle (Feitosa et al., 2005). The low initial school performance can affect as well the academic competence perception and other motivational dimensions, which by its turn affects effort and future performance (Stipek, 2001).

\section{Objetives and hypothesis}

In sum, dealing with school life challenges requires from students several skills, whose acquisition can be in some extent influenced by contextual factors, such as the SES. It is then our objective to analyse the influence that belonging to a higher or lower SES family can exert on students' success and adaptation, and to discuss some possibilities for school based interventions in order to balance those risks.

We hypothesized that students students from higher SES families present superior indicators of school success, not only expressed in (1) better performance, as research has been showing, but as well within (2) social and school life integration domains, such as the participation in school activities and quality of interpersonal relationships at school. It was also our hypothesis that students with higher SES are consequently (3) more satisfied with their school pathway, reporting a superior sense of accomplishment and balance about it. 


\section{Method}

\section{Participants}

Participants were 351 ninth to twelfth grade Portuguese students (212 females, about $60 \%)$ attending compulsory school ( $9^{\text {th }}$ grade, $\left.n=123\right)$, high school $\left(10^{\text {th }}\right.$ to $12^{\text {th }}$ grades, $n=$ 202 ) and professional training courses $(n=26)$. Students' majority was living in rural areas (about 64\%) and the remaining in urban areas. Ages varied between 14 and 18 years $\left(M_{\mathrm{Age}}=\right.$ $16 ; S D=1.43)$. A significant relationship between age and school level was found, $\chi^{2}(20, \mathrm{~N}=351)$ $=223.27, p<.001$, with a superior than expected number of older students for the level they were in. This is related to the fact that approximately half of the sample had at least one retention in the school path.

\section{Instrument}

We used for this study the School Path Questionnaire, SPQ (Carvalho \& Novo, 2010), a self-report instrument designed to collect information about several school life dimensions, including grades and retentions, and as well several significant school life adaptation domains. For the latter case, each item presented a five points Likert style scale, to which students had to respond, from "Totally false" to "Totally true". Each one of the variables mentioned above corresponded to the simple mean of its items, so the higher the result, the more frequent or applicable is the content related to them. Descriptive statistics and Cronbach's $\alpha$ for school life variables are presented in Table 1.

Table 1. Descriptive Statistics and Cronbach's Alfas for Each School

\section{Life Variable}

\begin{tabular}{llllll}
\hline Variable & Min. & Max. & $M(S D)$ & Nr items & $\alpha$ \\
\hline Grades Mean & 8.0 & 20 & $12.84(2.37)$ & - & - \\
Number of Retentions & 0 & 5 & $0.79(1.08)$ & - & - \\
School Achievement $^{\mathrm{a}}$ & 1.78 & 5 & $3.16(0.56)$ & 8 & .737 \\
School Transitions $^{\mathrm{b}}$ & 1.17 & 5 & $3.53(0.85)$ & 6 & .842 \\
Behaviour Problems $^{\mathrm{c}}$ & 1.0 & 3.22 & $1.49(0.45)$ & 10 & .845 \\
Risk Behaviours $^{\mathrm{d}}$ & 1.0 & 3.18 & $1.48(0.40)$ & 11 & .763 \\
Interpersonal Difficulties $^{\mathrm{e}}$ & 1.0 & 3.45 & $1.78(0.48)$ & 11 & .729 \\
Extracurricular Activities $^{\mathrm{f}}$ & 1.0 & 5 & $3.29(0.97)$ & 7 & .841 \\
Overall Satisfaction $^{\mathrm{g}}$ & 1.44 & 5 & $3.58(0.58)$ & 9 & .750 \\
\hline
\end{tabular}




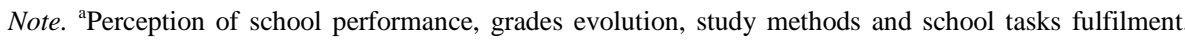
${ }^{b}$ Adaptation to school and year changes and transitions. ${ }^{\circ}$ Frequency of disruptive, acting-out and undisciplined behaviours. ${ }^{\mathrm{d}}$ Frequency of risky sexual behaviour, substance abuse, and eating problems. ${ }^{\mathrm{e}}$ Interpersonal problems involving conflicts, lack of social support, and social withdrawal. ${ }^{\mathrm{f}}$ Participation in extracurricular and leisure activities in and outside school. ${ }^{\mathrm{g}} \mathrm{Global}$ assessment and pleasure about school life; sense of fulfilment or accomplishment.
\end{abstract}

\title{
Procedures
}

SPQ was administered in one single session and in class context, during May and June, 2010, in several schools in the region of Madeira, Portugal. The results were thereafter processed and analysed with SPSS 17.0. In this study we resorted to parents' education level to define students' SES. Similarly to parents' income and occupations, their education level is one of the reference and commonly used criterion to categorize families SES (American Psychological Association, 2007; Marks et al., 2000). The sample was divided in four groups, each one corresponding to a different SES level. The arrangement for the different groups constitution, which gave a parsimonious response to all cases in the sample, was as follows: the first group (G1, low SES; $n=85$ ) was constituted by students whose parents' qualifications were inferior to the mandatory school at the time of data collection $\left(9^{\text {th }}\right.$ grade); students in the second group (G2, medium-low SES; $n=167$ ) had parents with completed mandatory school or only one of them with secondary education; in the third group (G3, medium SES; $n=74)$, students' parents qualifications were at secondary level ( $12^{\text {th }}$ grade) for both or at least one parent had a university degree; finally, in the fourth group (G4, highest SES; $n=21$ ) both students' parents had a university degree.

\section{Statistical Analysis}

In this quantitative cross-sectional study, statistical analysis for comparison of groups was made through a one way multivariate analysis of variance (MANOVA). Preliminary analysis revealed independence between SES and gender, $\chi_{(3, \mathrm{~N}=351)}^{2}=4.64, p=.200$, as well as between SES and age, $\chi_{(12 . \mathrm{N}=351)}^{2}=12.56, p=.402$, so we didn't perform differentiated analysis accordingly to those socio-demographic variables. We therefore considered as independent variable SES and as dependent variables (DV) each one of the school life dimensions. In the preliminary MANOVA assumptions testing and considering the critical value (9 DV) to assess the Mahanalobis distance values, we identified four multivariate outliers, which we decided to eliminate from the sample, so the assumptions could be fulfilled (Tabachnick \& Fidell, 2007). This decision was sustained by the necessity of fulfilment of the 
MANOVA assumptions and as well because the elimination of four cases did not significantly modify the sample size.

\section{Results}

Results firstly show significant differences between the SES groups, $F_{(27,979)}=3.19, p$ $<.001$, Wilks' $\Lambda=.78, \eta p^{2}=.08$. Considering the DV separately, we found that significant differences occur in most cases, as shown in Table 2, namely in school grades, number of retentions, school achievement, participation in extracurricular activities, interpersonal difficulties, adaptation to school transitions, and overall school path satisfaction. Contrarily to some other studies, no significant differences were found concerning behaviour problems. The effect sizes reveal that it is mostly in school performance related variables (e.g., grades, number of retentions and school achievement) that the differences are more significant, as the partial Eta squared values are situated in a moderate range (Maroco, 2007). This result supports the effects that literature has been reporting.

Post-hoc comparisons (Tukey) reveal it is the fourth group (highest SES) which differentiates most from the others in variables such as grades, number of retentions and in school achievement. In the adaptation to school transitions and interpersonal difficulties variables, the highest SES group distinguishes significantly from the low SES group (first group), reporting better adaptation to school year transitions and school changes, as well as lower incidence of interpersonal problems (conflicts, withdrawal and lack of family support). Finally, in the overall school path satisfaction, the highest SES group distinguishes from the lowest SES groups, reporting a more positive global assessment of the evolution through the school system and expressing a higher degree of satisfaction with the school life.

Table 2. Comparison of SES Groups in School Life Variables Results

\begin{tabular}{llrccc}
\hline Variable & SES & \multicolumn{1}{c}{$N$} & $M(S D)$ & $F_{(3,343)}$ & $\eta_{\mathrm{p}}{ }^{2}$ \\
\hline Grades Mean & Low & 85 & $12.14(1.98)$ & $17.01 * * *$ & .13 \\
& Medium-low & 167 & $12.47(2.14)$ & & \\
& Medium & 74 & $13.83(2.42)$ & & \\
& High & 21 & $15.14(2.66)$ & & \\
Number of Retentions & Low & 85 & $1.09(1.19)$ & $9.21 * * *$ & .08 \\
& Medium-low & 167 & $0.88(1.09)$ & & \\
& Medium & 74 & $0.39(0.82)$ & & \\
& High & 21 & $0.14(0.36)$ & & \\
\hline
\end{tabular}




\begin{tabular}{|c|c|c|c|c|c|}
\hline \multirow[t]{4}{*}{ School Achievement } & Low & 85 & $3.01(0.52)$ & $7.63^{* * *}$ & .06 \\
\hline & Medium-low & 167 & $3.11(0.53)$ & & \\
\hline & Medium & 74 & $3.27(0.60)$ & & \\
\hline & High & 21 & $3.61(0.65)$ & & \\
\hline \multirow[t]{4}{*}{ School Transitions } & Low & 85 & $3.35(0.85)$ & $3.41 *$ & .03 \\
\hline & Medium-low & 167 & $3.52(0.80)$ & & \\
\hline & Medium & 74 & $3.66(0.89)$ & & \\
\hline & High & 21 & $3.91(0.88)$ & & \\
\hline \multirow[t]{4}{*}{ Behaviour Problems } & Low & 85 & $1.48(0.38)$ & 0.62 n.s. & .00 \\
\hline & Medium-low & 167 & $1.49(0.44)$ & & \\
\hline & Medium & 74 & $1.51(0.55)$ & & \\
\hline & High & 21 & $1.36(0.31)$ & & \\
\hline \multirow[t]{4}{*}{ Risk Behaviours } & Low & 85 & $1.45(0.45)$ & 0.40 n.s. & .00 \\
\hline & Medium-low & 167 & $1.48(0.38)$ & & \\
\hline & Medium & 74 & $1.51(0.41)$ & & \\
\hline & High & 21 & $1.43(0.28)$ & & \\
\hline \multirow[t]{4}{*}{ Interpersonal Difficulties } & Low & 85 & $1.88(0.49)$ & $4.60 * *$ & .04 \\
\hline & Medium-low & 167 & $1.77(0.46)$ & & \\
\hline & Medium & 74 & $1.74(0.45)$ & & \\
\hline & High & 21 & $1.48(0.28)$ & & \\
\hline \multirow[t]{4}{*}{ Extracurricular Activities } & Low & 85 & $3.17(0.93)$ & $4.74 * *$ & .04 \\
\hline & Medium-low & 167 & $3.27(0.98)$ & & \\
\hline & Medium & 74 & $3.29(0.99)$ & & \\
\hline & High & 21 & $4.01(0.61)$ & & \\
\hline \multirow[t]{4}{*}{ Overall Satisfaction } & Low & 85 & $3.53(0.53)$ & $3.99 * *$ & .03 \\
\hline & Medium-low & 167 & $3.55(0.57)$ & & \\
\hline & Medium & 74 & $3.62(0.60)$ & & \\
\hline & High & 21 & $3.98(0.47)$ & & \\
\hline
\end{tabular}

\section{Discussion and conclusion}

In this short paper we intended to analyse, with a sample of Portuguese students, the effect of SES in several school life dimensions. Our main goal was to provide a wider perspective on the range of variables where differences could be observed according to students' SES. Globally, the results reveal a SES effect on different school life dimensions and corroborate what the literature has been mentioning concerning school success (Sirin, 2005). Moreover, we could verify that, beyond school grades, there is an influence of SES in 
several school life domains, in a trend that confirms our initial hypothesis, not only at the level of between-groups significant differences but specifically that higher SES students report more adaptation. This pattern is especially visible in the cluster of variables related to school performance, such as school grades, number of retentions and perceived school achievement, and as well in the adaptation to school transitions, extracurricular activities participation and global satisfaction about school life. In effect, we found that higher SES students have better grades, report higher levels of adaptation to transitions and are more satisfied and have a sense of higher accomplishment concerning their school life and evolution through time. We draw attention as well to their higher participation in extracurricular activities, which confirms the idea that they have more access and opportunities to put in practice and develop new skills and capacities (Bradley \& Corwyn, 2002; Feitosa et al., 2005). This view is confirmed by the less interpersonal difficulties that higher SES students report, which puts forward the ideia of more social support they might have.

Globally, these results confirm the investigation trend that shows the relevance of socio-demographic variables for students' school success and particularly the positive relationship between students' SES and their school success and integration (Almeida et al., 2005, 2006; Arnold \& Doctoroff, 2003; Bradley \& Corwyn, 2002; Caro et al., 2009; Martin, 2009; Saavedra, 2001; Sirin, 2005; Strenze, 2007). In fact, if individual students' characteristics exert a crucial influence in their adaptation and evolution through the academic path (Carvalho \& Novo, 2011), one cannot ignore the role that their life, family and community contexts play, especially in the availability of favourable conditions for success, such as cultural stimulation, valuing education, and incentives to learning and school investment, accessibility of positive role models, or access to material resources health and other services.

Given these results, we consider that schools and education systems must pay special attention to students who start school at less favourable social, cultural or economic conditions, especially in initial stages of schooling. In our view, some effort has to be done in order to "compensate" potential SES negative effects and prevent potential achievement difficulties derived from a lower SES. This might involve not only the availability of material resources related to learning, but as well the follow-up of students in riskier conditions or who don't have enough family support. We think the incentive of existing capacities and skills, as well as the creation of development opportunities (e.g., extracurricular activities) for students 
to engage in positive pathways and get involved in school life are also some favourable possibilities. Finally, we emphasize the importance of assuring that effective instruction is being delivered, not only through proper teachers' training, but as well through the existence of organised and ordered learning spaces that assure that students' who want to learn effectively can. In sum, if on one hand SES can be related to more or less favourable contextual conditions to school success, on the other hand, educational interventions and strategies - beyond individual characteristics - can play an important role in the prevention of negative effects of SES in students.

\section{Study limitations and recommendations for future research}

Being configured as a sort of pilot study on the influence os socio-demographic variables on school adaptation, this study has some limitations which must be taken into account. We consider the main limitations correspond to the fact this is a non-longitudinal study, and especially to the fact that data on school adaptation was collected only through a self-report intrument. In fact, data collection through time and from several sources would contribute to a more insightful study of SES impact through the school years. We must point out as well that although differences occurred according to SES, there are a large number of significant variables that exert great influence (e.g., intelligence, personality) and that need to be taken into consideration in more complex models related to school success and integration. We consider therefore that future investigation should take into account these aspects and focus the specific mechanisms through which SES exerts its effect and how it can be mediated and/or moderated by other variables, such as individual characteristics. 


\section{References}

Almeida, L.S., Gomes, C., Ribeiro, I.S., Dantas, J., Sampaio, M., Alves, M., Rocha, A., Paulo, E., Pereira, T., Nogueira, E., Gomes, F., Marques, L., Sá, C. \& Santos, F. (2005). Sucesso e insucesso no ensino básico: relevância de variáveis sócio-familiares e escolares em alunos do $5^{\circ}$ ano [Success and failure in basic education: relevance of social-family and school variables in $5^{\text {th }}$ grade students]. Proceedings of the VIII Galician-Portuguese Congress of Psychopedagogy (pp. 3629-3642). Braga, Portugal: University of Minho.

Almeida, L.S., Guisande, M.A., Soares, A.P. \& Saavedra, L. (2006). Acesso e sucesso no Ensino Superior em Portugal: questões de género, origem sócio-cultural e percurso académico dos alunos [Access and success in higher education in Portugal: Issues of gender, sociocultural origin and students' academic path]. Psicologia: Reflexão e Crítica, 19 (3), 507-514.

American Psychological Association (2007). Report of the APA task force on socioeconomic status. Washington, DC: Author.

Arnold, D.H. \& Doctoroff, G.L. (2003). The early education of socioeconomically disadvantaged children. Annual Review of Psychology, 54, 517-545.

Bradley, R.H. \& Corwyn, R.F. (2002). Socioeconomic status and child development. Annual Review of Psychology, 53, 371-399.

Caro, D.H, McDonald, J.T. \& Willms, J.D. (2009). Socio-economic status and academic achievement trajectories from childhood to adolescence. Canadian Journal of Education, 32 (3), 558-590.

Carvalho, R.G. \& Novo, R.F. (2010). Questionário sobre o Percurso Escolar [School Path Questionnaire]. Lisbon: Faculty of Psychology, University of Lisbon.

Carvalho, R.G. \& Novo, R.F. (2011, May). A personalidade prediz o sucesso academico? [Can personality predict academic achievement?]. Conference at International Congress "Education, Health e Social Development: Contributes to Psychological Adjustment”, Funchal, Portugal.

Feitosa, F.B., Matos, M.G., Del Prette, Z.A.P. \& Del Prette, A. (2005). Social support, socioeconomic level and school and social adjustment of Portuguese adolescents [Portuguese]. Temas em Psicologia, 13 (2), 129-138.

Marks, G.N., McMillan, J., Jones, F.L. \& Ainley, J. (2000). The measurement of socioeconomic status for the reporting of nationally comparable outcomes of schooling - Draft report. Canberra: Australian Council for Educational Research \& Australian National University.

Maroco, J. (2007). Análise estatística com a utilização do SPSS ( $3^{\mathrm{a}}$ ed.) [Statistical analysis with the SPSS ( $3^{\text {rd }}$ ed.)]. Lisbon: Sílabo. 
Martin, A.J. (2009). Age appropriateness and motivation, engagement, and performance in high school: Effects of age within cohort, grade retention, and delayed school entry. Journal of Educational Psychology, 101 (1), 101-114.

Pires, D. \& Morais, A. M. (2000). Contextos de socialização familiar e sucesso escolar [School success and contexts of family socialization]. In M.A. Fontaine (Ed.), Parecrias família-escolar e desenvolvimento da criança [Family-school partnership and child development]. Porto, Portugal: Asa.

Saavedra, L. (2001). Sucesso/insucesso escolar: a importância do sexo e do género [School success/unsuccess: the importance of gender and sex]. Psicologia, XV(1), 67-92.

Sirin, S.R. (2005). Socioeconomic status and academic achievement: A meta-analytic review of research. Review of Educational Research, 75, 417-453

Strenze, T. (2007). Intelligence and socioeconomic success: A meta-analytic review of longitudinal research. Intelligence, 35 (5), 401-426.

Stipek, D.J. (2001). Pathways to constructive lives: The importance of early school success. In A. Bohart \& D.J. Stipek (Eds.), Constructive and destructive behaviour: Implications for family, school, and society (pp. 291-315). Washington, DC: American Psychological Association.

Tabachnick, B. \& Fidell, L.S. (2007). Using multivariate statistics $\left(5^{\text {th }}\right.$ ed.). New York: Pearson. 
Renato Gil Carvalho y Rosa F. Novo

[This page intentionally left blank] 